\title{
Detection of Mycobacterium tuberculosis complex by nested polymerase chain reaction in pulmonary and extrapulmonary specimens*,**
}

\author{
Detecção do complexo Mycobacterium tuberculosis por nested polymerase \\ chain reaction em espécimes pulmonares e extrapulmonares
}

\author{
Adriana Antônia da Cruz Furini, Heloisa da Silveira Paro Pedro,
} Jean Francisco Rodrigues, Lilian Maria Lapa Montenegro, Ricardo Luiz Dantas Machado, Célia Franco, Haiana Charifker Schindler, Ida Maria Foschiani Dias Batista, Andrea Regina Baptista Rossit

\begin{abstract}
Objective: To compare the performance of nested polymerase chain reaction (NPCR) with that of cultures in the detection of the Mycobacterium tuberculosis complex in pulmonary and extrapulmonary specimens. Methods: We analyzed 20 and 78 pulmonary and extrapulmonary specimens, respectively, of 67 hospitalized patients suspected of having tuberculosis. An automated microbial system was used for the identification of Mycobacterium spp. cultures, and M. tuberculosis IS6110 was used as the target sequence in the NPCR. The kappa statistic was used in order to assess the level of agreement among the results. Results: Among the 67 patients, 6 and 5, respectively, were diagnosed with pulmonary and extrapulmonary tuberculosis, and the NPCR was positive in all of the cases. Among the 98 clinical specimens, smear microscopy, culture, and NPCR were positive in $6.00 \%$, $8.16 \%$, and $13.26 \%$, respectively. Comparing the results of NPCR with those of cultures (the gold standard), we found that NPCR had a sensitivity and specificity of 100\% and $83 \%$, respectively, in pulmonary specimens, compared with $83 \%$ and $96 \%$, respectively, in extrapulmonary specimens, with good concordance between the tests (kappa, 0.50 and 0.6867 , respectively). Conclusions: Although NPCR proved to be a very useful tool for the detection of $M$. tuberculosis complex, clinical, epidemiological, and other laboratory data should also be considered in the diagnosis and treatment of pulmonary and extrapulmonary tuberculosis.
\end{abstract}

Keywords: Tuberculosis/diagnosis; Tuberculosis/microbiology; Mycobacterium tuberculosis; Polymerase chain reaction.

\section{Resumo}

Objetivo: Comparar o desempenho da técnica nested polymerase chain reaction (NPCR) com aquele de culturas na detecção do complexo Mycobacterium tuberculosis em espécimes pulmonares e extrapulmonares. Métodos: Analisamos 20 e 78 espécimes pulmonares e extrapulmonares, respectivamente, de 67 pacientes hospitalizados com suspeita de tuberculose. Um sistema automatizado foi utilizado na identificação de culturas de Mycobacterium spp., e M. tuberculosis 1S6110 foi utilizada como sequência alvo na NPCR. A estatística kappa foi utilizada para verificar a concordância entre os resultados.Resultados: Entre os 67 pacientes, 6 e 5, respectivamente foram diagnosticados com tuberculose pulmonar e extrapulmonar, e a NPCR foi positiva em todos os casos. Entre os 98 espécimes clínicos, a baciloscopia, cultura e NPCR foram positivas em 6,00\%, 8,16\% e 13,26\%, respectivamente. Comparando-se os resultados da NPCR com aqueles da cultura (padrão ouro) nos espécimes pulmonares, a sensibilidade e a especificidade foram 100\% e $83 \%$, respectivamente, enquanto essas nos espécimes extrapulmonares foram $83 \%$ e $96 \%$ respectivamente, com boa concordância entre os testes (kappa, 0,50 e 0,6867, respectivamente). Conclusões: Embora a NPCR tenha se mostrado uma ferramenta muito útil na deteç̧ão do complexo $M$. tuberculosis, No entanto, os resultados positivos da NPCR devem ser associados à clínica, dados clínicos, epidemiológicos e outros dados laboratoriais devem também ser considerados no diagnóstico e tratamento da tuberculose pulmonar e extrapulmonar.

Descritores: Tuberculose/diagnóstico; Tuberculose/microbiologia; Mycobacterium tuberculosis; Reação em cadeia da polimerase.

*Study carried out at the São José do Rio Preto School of Medicine; in the Department of Mycobacteria, Adolfo Lutz Institute, São José do Rio Preto, Brazil; and at Aggeu Magalhães Research Center, Oswaldo Cruz Foundation, Recife, Brazil.

Correspondence to: Heloisa da Silveira Paro Pedro. Faculdade de Medicina de São José do Rio Preto, Avenida Brigadeiro Faria Lima, 5416, Vila São Pedro, CEP 15090-000, São José do Rio Preto, SP, Brasil.

Tel. 5517 3224-2602. E-mail: hsppedro@ial.sp.gov.br

Financial support: This study received financial support from the Brazilian Conselho Nacional de Desenvolvimento Cientifico e Tecnológico (CNPq, National Council for Scientific and Technological Development; Process no. 576297/2008-9)

Submitted: 1 February 2013. Accepted, after review: 24 September 2013.

**A versão completa em português deste artigo está disponível em www.jornaldepneumologia.com.br 


\section{Introduction}

The World Health Organization estimates that there were between 8.8 and 9.2 million new tuberculosis cases in 2010. ${ }^{(1)}$ In addition, it is estimated that 1.2 million of those cases are infected by HIV. Furthermore, it is estimated that 1.1 million deaths occurred in HIV-negative tuberculosis patients, which equates to 15 deaths per 100,000 population. Mortality is the most sensitive indicator of tuberculosis control measures $^{(2)}$; tuberculosis remains among the top ten causes of death worldwide. The goal of curing $85 \%$ of tuberculosis cases, set by the World Health Assembly in 1991, was not achieved in 2009 in 7 of the 22 countries with the highest burden of the disease, including Brazil (at 72\%). ${ }^{(3)}$

Diagnosis in an early stage of the disease is of paramount importance for treatment initiation, with direct consequences for individual disease control and, therefore, for public health initiatives aimed at the prevention of tuberculosis transmission. Therefore, it is necessary that clinical microbiology laboratories be able to quickly identify mycobacteria by means of microscopy and culture. However, sputum smear tests, although rapid and cost-effective, have low sensitivity and specificity, particularly in paucibacillary samples, and culture, even though it is considered the gold standard due to its high sensitivity, requires several weeks to produce a result. ${ }^{(4-8)}$

Currently, Brazil is one of the countries that, together, accounts for 80\% of tuberculosis cases, with an incidence of 70,977 cases in 2010..$^{(4,6)}$ For the majority of those cases, the diagnosis was based only on sputum smear test results; chest X-rays, cultures, and biochemical tests for Mycobacterium spp. were only carried out in patients with negative sputum smear results but with respiratory symptoms. ${ }^{(8,9)}$ These diagnostic limitations have encouraged the use of molecular tools with improved sensitivity, specificity, and speed, in order to detect mycobacteria in all clinical specimens. ${ }^{(5-8,10)}$ The new technologies that are being developed have recently redefined the diagnosis of tuberculosis, providing a basis for diagnostic laboratory techniques. ${ }^{(5,8)}$ The molecular diagnosis of tuberculosis by polymerase chain reaction (PCR) and primers with high specificity (98\%), with high variations in sensitivity (20-100\%), has been used in order to identify genetic targets in the bacillus. ${ }^{(7,11,12)}$
Despite the widespread use of conventional $\mathrm{PCR}$, modifications in the technique, such as the addition of one extra reaction (nested PCR), have increased its sensitivity and specificity. ${ }^{(6)}$ This might be due to the fact that it dilutes potential PCR inhibitors, which are commonly present in biological samples. ${ }^{(11)}$ Therefore, the possibility of having access to a molecular tool that leads to a more rapid diagnosis and that is effective for the detection of cases that are difficult to elucidate by conventional tests certainly helps decrease morbidity and improve tuberculosis control. The aim of the present study was to evaluate the technique of nested PCR targeting the insertion sequence 156110 in Mycobacterium tuberculosis and to compare the results with those obtained in cultures of samples from patients suspected of having pulmonary or extrapulmonary tuberculosis.

\section{Methods}

This study was carried out between February and December of 2009. The patients included in the study were submitted to physical evaluation and sample collection at the Hospital de Base, a referral center for the diagnosis and treatment of tuberculosis located in the city São José do Rio Preto, Brazil. Epidemiological and clinical data were obtained from medical records in accordance with a protocol approved by the Research Ethics Committee of Faculdade de Medicina de São José do Rio Preto (São José do Rio Preto School of Medicine; Protocol no. 064/2009). The presence of HIV antibodies, identified by ELISA and confirmed by Western blot, indicated HIV seropositivity.

All of the patients included in the study were over 18 years of age, were immunosuppressed (due to immunosuppression therapy, autoimmune disease, organ transplantation, or HIV-positivity), and presented with clinical symptoms and signs suggestive of pulmonary or extrapulmonary tuberculosis. Our sample comprised 67 hospitalized patients, and 98 clinical specimens were collected, of which 20 were pulmonary specimens (sputum, BAL fluid, or gastric lavage fluid), and 78 were extrapulmonary specimens (blood, cerebrospinal fluid, lymph node aspirate, urine, pleural fluid, secretion from ganglia, pleura fragment, liver fragment, ascitic fluid, bone marrow aspirate, or biopsy specimens). The number of specimens collected from the patients ranged from one 
to three, according to physician requests. The diagnostic confirmation of tuberculosis was based on the following criteria: clinical and radiological evidence of tuberculosis confirmed by laboratory tests, isolation of $M$. tuberculosis in clinical specimens by direct smear microscopy or culture (gold standard), and evident clinical improvement after antimycobacterial treatment.

In brief, direct smear microscopy was performed using Ziehl-Neelsen staining, and an automated microbial system (BacT/ALERT MP; Organon Teknika Corp., Durham, NC, USA) was used for the identification of Mycobacterium spp. in cultures. The strains were identified by phenotypic methods. ${ }^{(13)}$ Genotyping was carried out by PCR-restriction enzyme analysis in accordance with Chimara et al., ${ }^{(14)}$ although with modifications.

Blood samples were collected in 5-mL tubes containing EDTA, and peripheral blood mononuclear cells were isolated by density gradient centrifugation (Ficoll-Histopaque) for future extraction of the DNA. ${ }^{(15-17)}$ For solid organs, 2.0-mm punch biopsy samples were collected. All clinical samples were kept at $-20^{\circ} \mathrm{C}$ until DNA extraction, which was performed in accordance with the method described by Rossetti et al. ${ }^{(18)}$ with modifications by Lima et al. ${ }^{(11,18,19)}$ In brief, a $500-\mu \mathrm{L}$ aliquot of the sample was centrifuged at 13,000 rpm for $10 \mathrm{~min}$ and washed three times in Tris-EDTA (TE). The pellet was resuspended in $100 \mu \mathrm{L}$ of TE and heated at $100^{\circ} \mathrm{C}$ for $10 \mathrm{~min}$. The supernatant was transferred to a different tube, and $5 \mu \mathrm{L}$ of resin were added (Sephaglas BandPrep Kit; Amersham-Pharmacia Biotech, Uppsala, Sweden); an aliquot of sodium iodide solution $(0.9 \mathrm{~g} / \mathrm{mL})$ was added to the final volume. The tube was shaken for $5 \mathrm{~min}$ and incubated at room temperature for $5 \mathrm{~min}$. After centrifuging the tube for $1 \mathrm{~min}$ and discarding the supernatant, we added $200 \mu \mathrm{L}$ of iced $70 \%$ ethanol; the tube was then shaken, after which it was centrifuged for $1 \mathrm{~min}$. The resulting pellet was kept at room temperature for $60 \mathrm{~min}$, in order to complete the drying process, and resuspended in $40 \mu \mathrm{L}$ of $1 \times$ TE. The tube was incubated in a water bath at $50^{\circ} \mathrm{C}$ for $10 \mathrm{~min}$. Subsequently, the tube was centrifuged for $1 \mathrm{~min}$, and the supernatant was transferred to another tube and stored at $-20^{\circ} \mathrm{C}$ until processing. ${ }^{(11,18)}$

For the nested PCRs, 1S6110 of M. tuberculosis was used as the target sequence (GenBank accession no. 215310.1). The reactions were performed in accordance with Ritis et al. ${ }^{(17)}$ The following primers were used: sense (TJ3 5'-ATC CCC TAT CCG TAT GGT G-3'); antisense (TJ5 5'-CCG CAA AGT GTG GCT AAC-3'); sense (STAN3 5'-GTC GAG TAC GCC TTC TTG TT-3'); and antisense (OLI 5 5'-AAC GGC TGA TGA CCA AAC-3'). The PCR used a final volume of $50 \mu \mathrm{L}$ (1× buffer, $50 \mathrm{mM} \mathrm{MgCl}, 10 \mathrm{pmol} / \mu \mathrm{L}$ of each oligonucleotide, $0.2 \mu \mathrm{M}$ dNTP, and $2 \mathrm{U}$ Taq DNA polymerase [Invitrogen life Technologies, Carlsbad, CA, USA]). The amplification process consisted of an initial denaturation step of $94^{\circ} \mathrm{C}$ for $3 \mathrm{~min}, 30$ denaturing cycles (at $94^{\circ} \mathrm{C}$ for $1 \mathrm{~min}, 57^{\circ} \mathrm{C}$ for $1 \mathrm{~min}$, and $72^{\circ} \mathrm{C}$ for $1 \mathrm{~min}$ ), followed by a final extension at $72^{\circ} \mathrm{C}$ for $5 \mathrm{~min}$. The second PCR was performed using $3 \mu \mathrm{L}$ of the product of the first PCR under similar conditions to those described above, but with an annealing temperature of $60^{\circ} \mathrm{C}$. DNA of the H37Rv strain of $M$. tuberculosis and PCR mix alone were used as positive and negative controls, respectively. The result was analyzed by electrophoresis on $2 \%$ agarose gel, stained with ethidium bromide, and visualized in an ultraviolet transilluminator (Fisher-Biotech, Fairlawn, NJ, USA), resulting in a 316-bp fragment.

Statistical analyses were performed with the Epi lnfo statistical package, version 6.0. The kappa statistic was used in order to assess the level of agreement among the results. ${ }^{(20)}$ The level of significance was set at 5\%.

\section{Results}

Our sample comprised 67 individuals, 63.7\% being male. The mean age of the patients was $40.10 \pm 3.66$ years (range, 18-87 years). The most common comorbidity was HIV/AIDS, in 41 patients.

Tuberculosis was diagnosed in 11 individuals (16.41\%), 5 being diagnosed with pulmonary tuberculosis and the remaining with extrapulmonary tuberculosis (pleural tuberculosis in 3, meningeal tuberculosis in 2, and miliary tuberculosis in 1). All culture isolates were confirmed by $M$. tuberculosis genotyping. Nested PCR was positive in all of the cases of confirmed tuberculosis, as shown in Table $1 . \ln 4$ of the tuberculosis patients, positive laboratory results were obtained only by the molecular technique ( $p=0.110$; Fisher's exact test).

Of the 98 clinical specimens analyzed, 6.00\%, $8.16 \%$, and $13.26 \%$, respectively, showed positive 
results in smear microscopy, culture, and nested PCR, as summarized in Table 1. Culture was negative in 2 of the samples with positive smear microscopy results, whereas smear microscopy was negative in 4 of the samples with positive culture results.

By comparing the results of nested PCR with those of cultures in pulmonary samples (Table 2), we found that the sensitivity and specificity of nested PCR were 100\% and 83\%, respectively. The positive and negative predictive values were $40 \%$ and $100 \%$, respectively, with good concordance between the tests (kappa $=0.50 ; p=0.25$; McNemar's test). Regarding extrapulmonary samples (Table 2), sensitivity, specificity, positive predictive value, and negative predictive value were, respectively, 83.0\%, 96.0\%, 62.5\%, and
98.5\%, with good concordance between the tests (kappa $=0.6867 ; p=0.625 ;$ McNemar's test).

\section{Discussion}

The early diagnosis of tuberculosis is essential for prompt treatment and effective control of the disease. ${ }^{(5)}$ This is particularly true in cases of extrapulmonary tuberculosis, because various factors can complicate the diagnosis of the disease. Due to the paucibacillary nature of extrapulmonary tuberculosis, studies have shown a variability in positive culture results (from 12\% to $80 \%$ ) and a variety of clinical samples/biological tissues, which implies a non-uniform distribution of the bacillus, as well as the presence of nonspecific signs and symptoms..$^{(10,12,19-21)}$ In our study, pleural tuberculosis was diagnosed in 2 HIV-negative

Table 1 - Clinical, epidemiological, and laboratory data of the eleven patients with confirmed pulmonary or extrapulmonary tuberculosis.

\begin{tabular}{|c|c|c|c|c|c|c|}
\hline \multirow[t]{2}{*}{ Patient $^{\mathrm{a}}$} & \multirow{2}{*}{$\begin{array}{l}\text { Form of } \\
\text { tuberculosis }\end{array}$} & \multirow{2}{*}{$\begin{array}{l}\text { Type of } \\
\text { sample }\end{array}$} & \multicolumn{3}{|c|}{ Results } & \multirow[t]{2}{*}{ Outcome } \\
\hline & & & $\begin{array}{c}\text { Smear } \\
\text { microscopy }\end{array}$ & Culture & $\begin{array}{l}\text { Nested } \\
\text { PCR }\end{array}$ & \\
\hline 1 & Pulmonary & Blood & - & - & + & Death/NTB \\
\hline 2 & Pulmonary & Blood & - & - & + & Cure \\
\hline 3 & Pleural & Blood & - & - & + & Death/NTB \\
\hline 4 & Pleural & Pleural fluid & + & - & + & Cure \\
\hline 5 & Pulmonary & Blood & + & + & + & Death/TB \\
\hline 6 & Pulmonary & Sputum & + & - & + & Death/NTB \\
\hline \multirow[t]{3}{*}{7} & Pulmonary & Sputum & + & + & + & Cure \\
\hline & & CSF & + & + & + & \\
\hline & & Blood & - & - & - & \\
\hline 8 & Meningeal & CSF & - & + & + & Cure \\
\hline 9 & Meningeal & CSF & - & + & + & Cure \\
\hline \multirow[t]{3}{*}{10} & Miliary & Sputum & + & + & + & Death/NTB \\
\hline & & CSF & - & + & - & \\
\hline & & Blood & - & + & + & \\
\hline 11 & Pleural & Pleural fluid & - & - & + & Abandonment \\
\hline
\end{tabular}

PCR: polymerase chain reaction; Death/NTB: death due to causes other than tuberculosis; Death/TB: death due to tuberculosis; and CSF: cerebrospinal fluid. aPatients 1 to 4 were HIV-negative, and patients 5 to 11 were HIV-positive. Culture vs. nested PCR (negative/positive): $7 \times 8 / 2 \times 13$ ( $p=0.110$; Fisher's exact test).

Table 2 - Culture and nested polymerase chain reaction for the detection of Mycobacterium tuberculosis in pulmonary and extrapulmonary samples.

\begin{tabular}{|c|c|c|c|c|c|}
\hline \multirow[t]{4}{*}{ Nested PCR } & \multicolumn{4}{|c|}{ Culture } & \multirow[t]{4}{*}{ Total } \\
\hline & \multirow{2}{*}{\multicolumn{2}{|c|}{$\begin{array}{c}\text { Extrapulmonary samples } \\
(\mathrm{n}=78)\end{array}$}} & \multirow{2}{*}{\multicolumn{2}{|c|}{$\begin{array}{c}\text { Pulmonary samples } \\
(\mathrm{n}=20)\end{array}$}} & \\
\hline & & & & & \\
\hline & $(+)$ & $(-)$ & $(+)$ & $(-)$ & \\
\hline$(+)$ & 5 & 3 & 2 & 3 & 13 \\
\hline$(-)$ & 1 & 69 & 0 & 15 & 85 \\
\hline Total & 6 & 72 & 2 & 18 & 98 \\
\hline
\end{tabular}

PCR: polymerase chain reaction. 
patients, corroborating the findings of a study reporting that pleural tuberculosis is prevalent in extrapulmonary cases in HIV-negative patients. ${ }^{(22)}$ Approximately 50\% of HIV-positive individuals with tuberculosis develop extrapulmonary forms. ${ }^{(12,20,21,23)}$ Despite the small number of HIV-positive patients included in the present study, our results show a predominance of extrapulmonary tuberculosis (57\%).

Various tests based on PCR techniques using commercial kits and in-house tests are being evaluated. The nested PCR technique, by targeting $1 \mathrm{~S} 6110$ in order to identify the M. tuberculosis complex, ${ }^{(4)}$ provides variable sensitivity and specificity, depending on the laboratory, clinical specimen, bacillary load, cell lysis, and technical parameters. ${ }^{(10)}$ Molecular techniques have greatly improved the detection of mycobacteria in lymph nodes and in various body fluids (aspirates, cerebrospinal fluid, ascitic fluid, and pleural fluid). However, due to the variable sensitivity and specificity in different studies, positive results should be interpreted in conjunction with clinical findings. ${ }^{(21)}$ In the present study, the proportion of positive results in the individuals diagnosed with pulmonary or extrapulmonary tuberculosis using nested PCR $(100 \%)$ was higher than in other studies using the same target gene and carried out in Brazil, ${ }^{(6)}$ India, ${ }^{(21)}$ and Greece. ${ }^{(17)}$

The discordance between the molecular method and smear microscopy in pulmonary and extrapulmonary samples in our study (in 1 and in 6 samples, respectively) might be directly related to the low sensitivity of the phenotyping technique, the paucibacillary nature of samples, or even the absence of infection by AFB, as observed by other authors. ${ }^{(12,15,20)}$ Negi et al. ${ }^{(19)}$ reported that a molecular technique targeting 1S6110 showed high positivity in pulmonary and extrapulmonary samples (90\% and 77\%, respectively), whereas smear microscopy showed low positivity (49\% and 24\%, respectively). Similarly, Barani et al., ${ }^{(10)}$ when studying 19 pulmonary and 104 extrapulmonary samples, obtained higher positivity with a molecular technique targeting 1S6110 and TCR4 than with the smear method (17 similar and 12 divergent results). It is of note that a reported 50\% of tuberculosis cases are classified as negative on the basis of smear microcopy results. ${ }^{(24)}$ In addition, smear microcopy was not performed in $32.43 \%$ of the reported cases of tuberculosis in Brazil in 2010.(1)

When we compared nested PCR and culture results in pulmonary samples, we found that 3 of the samples showed positive nested PCR results but negative culture results. The negative results in the cultures might be due to co-infection with HIV in 2 of the patients and kidney transplantation in 1 (Table 1) or to the characteristics of paucibacillary infections. ${ }^{(6,12)}$ Various factors can influence the result of cultures, such as the number of organisms present in the specimen, the methods of sample collection, previous treatments, and the processing method. In addition, the solutions used for digestion/ decontamination of the samples can damage the mycobacteria. ${ }^{(4,25)}$

In the present study, the molecular results supported the clinical and diagnostic criteria widely accepted for the diagnosis of tuberculosis. The sensitivity and specificity found for nested PCR in our study (100\% and 83\%, respectively) are higher than those reported in previous studies using molecular techniques targeting the 156110 gene in sputum samples (88-98\% and $15-100 \%$, respectively). ${ }^{(5,12,23)}$ This difference might be attributable to the volume and type of samples, as well as to the different molecular typing protocols employed in different laboratories. ${ }^{(11,26,27)}$ Hence, the correlation of the results with the clinical profile of the patient is essential for the diagnosis of tuberculosis, and the definition of the disease can therefore be established from negative cultures after the therapeutic test. ${ }^{(26)}$ This was found in 3 of our patients who had positive nested PCR results and negative culture results in their pulmonary samples, 2 of whom were cured after treatment and 1 of whom was noncompliant with the treatment. In addition, 2 patients died before the beginning of the recommended tuberculosis treatment. As to the concordance between nested PCR and culture, although the kappa coefficient (0.50) was lower than that reported in other studies, carried out in India (kappa $=0.6-0.8)$ and in Brazil (kappa $=$ 0.78 ), the concordance was good.

Regarding extrapulmonary samples, nested PCR was positive in 3 of the blood samples with negative culture results, and negative in 1 of the cerebrospinal fluid samples with a positive culture result. This false-negative result in a cerebrospinal fluid sample (Table 1) might be 
related to the absence of copies of the 156110 gene, as previously described in studies conducted in southeast Asia, Denmark, Tunisia, India, and Vietnam, indicating the need to incorporate additional targets, such as TRC4, in order to improve molecular detection. ${ }^{(7,10)}$ However, to our knowledge, no study to date has reported the absence of this element in $M$. tuberculosis strains in Brazil, and various studies have reported that this sequence is the most sensitive in order to detect the M. tuberculosis complex. ${ }^{(9,17)}$ Another factor could be the presence of molecular reaction inhibitors in up to $18.6 \%$ of extrapulmonary specimens. ${ }^{(5)}$

In Brazil, the prevalence of M. tuberculosis isolated in cultures ranges from $15.0 \%$ to $25.6 \%,{ }^{(28,29)}$ the highest values being obtained prior to the highly active antiretroviral therapy era. Positive nested PCR results in blood samples led to the diagnosis of pulmonary tuberculosis in 2 HIV-negative patients and in 1 HIV-positive patient, as well as to the diagnosis of extrapulmonary tuberculosis in 1 HIV-negative patient and in 1 HIV-positive patient. In those blood samples, smear microscopy and culture were positive in only 1 and 2 samples, respectively; this might be due to the small number of bacilli in the circulation..$^{(6,7)}$ In fact, the sensitivity of PCR in peripheral blood mononuclear cells, as used here, has been reported to be better than is that of culture, both having similar specificity. ${ }^{(11,16,29)} \mathrm{In}$ addition, clinical specimens, such as cerebrospinal fluid, blood, and sputum, have been described as good substrates for $\mathrm{PCR}^{(26)}$ with good concordance ( $k$ appa $=0.6867 ; p=0.625$; McNemar's test), as in our results, in which the level of positivity in extrapulmonary samples was higher when nested PCR was used ( $p=0.0042)$, thus corroborating the findings of Noussair et al. ${ }^{(21)}$ Different rates of sensitivity were described using the molecular methodology for this type of sample in studies conducted in France ${ }^{(21)}$ and India ${ }^{(12)}$ (86.6\% and $90 \%$, respectively). If standardization studies using the same molecular target, DNA extraction method, and PCR optimization were validated in different laboratories, the sensitivity of the test could be improved and, consequently, so could its concordance.

In the present study, a positive nested PCR result, associated with the clinical features, was used as the single laboratory criterion for the diagnosis of 4 patients ( 2 with pulmonary tuberculosis and 2 with extrapulmonary tuberculosis), because it was the only test producing positive results (Table 1); the lack of isolates in cultures might be mainly due to the paucibacillary character of the samples. Although the difference is not significant in this situation, diagnosis is often established only by clinical and radiological data, even if the culture and sputum smear testing are negative. In such cases, molecular analysis can help establish specific antimycobacterial therapy and, consequently, contribute to reduce empirical treatment, which has been currently used in almost $27 \%$ of suspected pulmonary tuberculosis cases. In addition, it can help control the spread of the bacillus ${ }^{(11)}$ and prevent more severe clinical evolution, mainly in HIV-positive patients. However, the current Brazilian guidelines on tuberculosis do not include positive molecular results in the definition of tuberculosis cases; as a rule, the use of this method has been restricted to certain referral and research centers in Brazil. ${ }^{(9)}$

lt is worth mentioning that clinical screening that is carefully designed to study the disease caused by mycobacteria, together with similar attention to the collection and transport of biological samples, are factors that contributed to the isolation of a higher rate of $M$. tuberculosis strains than was expected at our hospital. The present study corroborates the results obtained at a referral center for the diagnosis of tuberculosis in the city of São José do Rio Preto (XV Subdivision of the São Paulo State Health Department), in which a 50\% increase in the number of isolates was observed during the study period. ${ }^{(25)}$

The results of the nested PCR assay revealed good agreement with those of the culture. The specificity and sensitivity achieved with this relatively simple molecular approach can be seen as an important contribution to the future establishment of a protocol for the molecular detection of $M$. tuberculosis complex in pulmonary and extrapulmonary samples. In addition, this methodology could reduce the time required for the appropriate diagnosis of tuberculosis.

\section{References}

1. World Health Organization [homepage on the Internet]. Geneva: World Health Organization. [cited 2012 May 10]. Brazil - Tuberculosis profiles. Available from: https:// extranet.who.int/sree/Reports?op=RepletCtname=0\%2FWHO_ HQ_Reports\%2FG2\%2FPROD\%2FEXT\%2FTBCountryP rofilectlS02 $=$ BREtouttype $=$ html 
2. World Health Organization [homepage on the Internet]. Geneva: World Health Organization. [cited 2012 Mar 18]. HIV/AIDS. Available from: http://www.who.int/ hiv/topics/tb/en

3. REDE-TB - Rede Brasileira de Pesquisas em Tuberculose [homepage on the Internet]. Rio de Janeiro: Rede Brasileira de Pesquisas em Tuberculose. [cited 2012 Jul 10]. Tuberculose, o 'mal do século' XXI. Available from: http://redetb.org/noticias/155-noticias-abr2012/1681tuberculose-o-mal-do-seculo-xxi

4. Ani A, Okpe S, Akambi M, Ejelionu E, Yakubu B, Owolodun 0 , et al. Comparison of a DNA based PCR method with conventional methods for the detection of $\mathrm{M}$. tuberculosis in Jos, Nigeria. J Infect Dev Ctries. 2009;3(6):470-5. http://dx.doi.org/10.3855/jidc.420 PMid:19762962

5. Cheng VC, Yew WW, Yuen KY. Molecular diagnostics in tuberculosis. Eur J Clin Microbiol Infect Dis. 2005;24(11):711-20. http://dx.doi.org/10.1007/s10096005-0039-1 PMid:16283213

6. da Cruz HL, de Albuquerque Montenegro R, de Araújo Lima JF, da Rocha Poroca D, da Costa Lima JF, Maria Lapa Montenegro L, et al. Evaluation of a nested-PCR for mycobacterium tuberculosis detection in blood and urine samples. Braz J Microbiol. 2011;42(1):321-9. http://dx.doi.org/10.1590/S1517-83822011000100041 PMid:24031638 PMCid:PMC3768939

7. Ereqat S, Bar-Gal GK, Nasereddin A, Said S, Greenblatt CL, Azmi K, et al. Pulmonary tuberculosis in the West Bank, Palestinian Authority: molecular diagnostic approach. Trop Med Int Health. 2011;16(3):360-7. http://dx.doi. org/10.1111/j.1365-3156.2010.02697.x PMid:21159079

8. Lawn SD, Zumla Al. Tuberculosis. Lancet. 2011;378(9785):57-72. http://dx.doi.org/10.1016/ S0140-6736(10)62173-3

9. Conde MB, Melo FA, Marques AM, Cardoso NC, Pinheiro VG, Dalcin Pde T, et al. 111 Brazilian Thoracic Association Guidelines on tuberculosis. J Bras Pneumol. 2009;35(10):1018-48. PMid:19918635

10. Barani R, Sarangan G, Antony T, Periyasamy S, Kindo AJ, Srikanth P. Improved detection of Mycobacterium tuberculosis using two independent PCR targets in a tertiary care centre in South India. J Infect Dev Ctries. 2012;6(1):46-52. PMid:22240428

11. Lima JF, Montenegro LM, Montenegro Rde A, Cabral MM, Lima AS, Abath FG, et al. Performance of nested PCR in the specific detection of Mycobacterium tuberculosis complex in blood samples of pediatric patients. J Bras Pneumol. 2009;35(7):690-7. http://dx.doi.org/10.1590/ S1806-37132009000700011 PMid:19669008

12. Sekar B, Selvaraj L, Alexis A, Ravi S, Arunagiri K, Rathinavel L. The utility of IS6110 sequence based polymerase chain reaction in comparison to conventional methods in the diagnosis of extra-pulmonary tuberculosis. Indian J Med Microbiol. 2008;26(4):352-5. http://dx.doi. org/10.4103/0255-0857.43575 PMid:18974489

13. Kent PT, Kubica GP. Public health mycobacteriology: a guide for the level 111 laboratory. Atlanta: U.S. Dept. of Health and Human Services, Public Health Service, Centers for Disease Control; 1985.

14. Chimara E, Ferrazoli L, Ueky SY, Martins MC, Durham AM, Arbeit RD, et al. Reliable identification of mycobacterial species by PCR-restriction enzyme analysis (PRA)-hsp65 in a reference laboratory and elaboration of a sequencebased extended algorithm of PRA-hsp65 patterns. BMC
Microbiol. 2008;8:48. http://dx.doi.org/10.1186/14712180-8-48 PMid:18366704 PMCid:PMC2323382

15. Gopinath K, Singh S. Multiplex PCR assay for simultaneous detection and differentiation of Mycobacterium tuberculosis, Mycobacterium avium complexes and other Mycobacterial species directly from clinical specimens. J Appl Microbiol. 2009;107(2):425-35. http://dx.doi. org/10.1111/j.1365-2672.2009.04218.x PMid:19302308

16. Rebollo MJ, San Juan Garrido R, Folgueira D, Palenque E, Díaz-Pedroche C, Lumbreras C, et al. Blood and urine samples as useful sources for the direct detection of tuberculosis by polymerase chain reaction. Diagn Microbiol lnfect Dis. 2006;56(2):141-6. http://dx.doi. org/10.1016/j.diagmicrobio.2006.03.018 PMid:16698218

17. Ritis K, Tzoanopoulos D, Speletas M, Papadopoulos E, Arvanitidis K, Kartali S, et al. Amplification of $1 S 6110$ sequence for detection of Mycobacterium tuberculosis complex in HIV-negative patients with fever of unknown origin (FU0) and evidence of extrapulmonary disease. J Intern Med. 2000;248(5):415-24. http://dx.doi. org/10.1046/j.1365-2796.2000.00750.x PMid:11123506

18. Rossetti ML, Jardim SB, Rodrigues VF, Moura AR, Oliveira $\mathrm{H}$, Zaha A. Improvement of Mycobacterium tuberculosis detection in clinical samples using DNA purified by glass matrix. J Microbiol Methods.1997;28(2):139-46. http:// dx.doi.org/10.1016/S0167-7012(97)00978-0

19. Negi SS, Anand R, Pasha ST, Gupta S, Basir SF, Khare $\mathrm{S}$, et al. Diagnostic potential of 1S6110, 38kDa, 65kDa and $85 \mathrm{~B}$ sequence-based polymerase chain reaction in the diagnosis of Mycobacterium tuberculosis in clinical samples. Indian J Med Microbiol. 2007;25(1):43-9. http:// dx.doi.org/10.4103/0255-0857.31061 PMid:17377352

20. Noussair L, Bert F, Leflon-Guibout V, Gayet N, NicolasChanoine $\mathrm{MH}$. Early diagnosis of extrapulmonary tuberculosis by a new procedure combining broth culture and PCR. J Clin Microbiol. 2009;47(5):1452-7. http:// dx.doi.org/10.1128/JCM.00066-09 PMid:19321729 PMCid:PMC2681850

21. Purohit MR, Mustafa T, Wiker HG, Sviland L. Rapid diagnosis of tuberculosis in aspirate, effusions, and cerebrospinal fluid by immunocytochemical detection of Mycobacterium tuberculosis complex specific antigen MPT64. Diagn Cytopathol. 2012;40(9):782-91. http:// dx.doi.org/10.1002/dc.21637 PMid:21416644

22. Portal Saúde [homepage on the Internet]. Brasília: Ministério da Saúde. [cited 2011 Jun 06]. Informe Técnico de Tuberculose. Novo sistema de tratamento da tuberculose para adultos e adolescentes no Brasil. [Adobe Acrobat document, 8p.]. Available from: http:// portal.saude.gov.br/portal/arquivos/pdf/informe_tb_ julho10_certo_22_07_2010.pdf

23. Sharma SK, Mohan A. Extrapulmonary tuberculosis. Indian J Med Res. 2004;120(4):316-53. PMid:15520485

24. Haldar S, Chakravorty S, Bhalla M, De Majumdar S, Tyagi JS. Simplified detection of Mycobacterium tuberculosis in sputum using smear microscopy and PCR with molecular beacons. J Med Microbiol. 2007;56(Pt 10):1356-62. http://dx.doi.org/10.1099/jmm.0.47265-0 PMid:17893174

25. Pedro Hda S, Pereira Ml, Goloni Mdo R, Ueki SY, Chimara E. Nontuberculous mycobacteria isolated in São José do Rio Preto, Brazil between 1996 and 2005. J Bras Pneumol. 2008;34(11):950-5. http://dx.doi.org/10.1590/ S1806-37132008001100010 PMid:19099102 
26. Bollela VR, Sato DN, Fonseca BA. Problems in the standardization of the polymerase chain reaction for the diagnosis of pulmonary tuberculosis [Article in Portuguese]. Rev Saude Publica. 1999;33(3):281-6. http://dx.doi.org/10.1590/S0034-89101999000300009 PMid:10457001

27. Runa F, Yasmin M, Hoq MM, Begum J, Rahman AS, Ahsan CR. Molecular versus conventional methods: clinical evaluation of different methods for the diagnosis of tuberculosis in Bangladesh. J Microbiol Immunol Infect. 2011;44(2):101-5. http://dx.doi.org/10.1016/j. jmii.2010.05.001 PMid:21439511
28. Oplustil CP, Leite OH, Oliveira MS, Sinto SI, Uip DE, Boulos $\mathrm{M}$, et al. Detection of mycobacteria in the bloodstream of patients with acquired immunodeficiency syndrome in a university hospital in Brazil. Braz J Infect Dis. 2001;5(5):252-9. http://dx.doi.org/10.1590/S141386702001000500003 PMid:11779451

29. Nakatani SM, Burger M, Assef MC, Brockelt SR, Cogo LL, Messias-Reason 1J. Efficient method for mycobacterial DNA extraction in blood cultures aids rapid PCR identification of Mycobacterium tuberculosis and Mycobacterium avium. Eur J Clin Microbiol Infect Dis. 2004;23(11):851-4. http:// dx.doi.org/10.1007/s10096-004-1236-z PMid:15558344

\section{About the authors}

\section{Adriana Antônia da Cruz Furini}

Professor. São José do Rio Preto School of Medicine, São José do Rio Preto, Brazil.

\section{Heloisa da Silveira Paro Pedro}

Scientific Researcher. Department of Mycobacteria, Adolfo Lutz Institute, São José do Rio Preto, Brazil.

\section{Jean Francisco Rodrigues}

Pharmacy Student. Rio Preto University Center, São José do Rio Preto, Brazil.

\section{Lilian Maria Lapa Montenegro}

Biologist. Aggeu Magalhães Research Center, Oswaldo Cruz Foundation, Recife, Brazil.

\section{Ricardo Luiz Dantas Machado}

Researcher in Public Health. Evandro Chagas Institute, Belém, Brazil.

\section{Célia Franco}

Physician. Regional Foundation School of Medicine, São José do Rio Preto, Brazil.

\section{Haiana Charifker Schindler}

Researcher. Aggeu Magalhães Research Center, Oswaldo Cruz Foundation, Recife, Brazil.

\section{Ida Maria Foschiani Dias Batista}

Researcher. Lauro de Souza Lima Institute, Bauru, Brazil.

\section{Andrea Regina Baptista Rossit}

Professor. Fluminense Federal University, Niterói, Brazil. 